\title{
Family Support in Management of Lactation Management in Mother With Children During Pandemic Covid-19
}

\author{
Rimawati*, Heru Suwardianto \\ Baptist Hospital Health Collage, Kediri, Indonesia \\ *rimawati150210@gmail.com
}

\begin{abstract}
Family social support provides benefits for mothers in giving ASI (Air Susu Ibu) to babies in the form of physical comfort and psychological comfort. One of the factors that influence lactation management compliance is family social support. This study aims to link the Relationship of Family Support with the success of lactation management during the Pandemic COVID-19 in the Pesantren District of Kediri City.

Research Design using Cross-Sectional Design. The population is all mothers with infants in the Pesantren District of Kediri City using the incidental sampling technique, with a sample of 30 respondents. The Independent variable is Family Social Support and the Dependent variable is Lactation Management. The instrument uses a questionnaire. Statistical tests using the spearmen rho

The results showed that the most supportive assessment of family support was as good as 18 respondents (60\%), Instrumental Support was mostly as good as 18 respondents (60\%), the most information support was good as many as 15 respondents $(50 \%)$ The most emotional support is good as many as 15 respondents (50\%). The results of the study using the Rho spearman test obtained $\mathrm{p}=0.025$ with a Correlation Coefficient of 0.612 which means there is a strong relationship between family support and lactation management. Family support needs to be improved in the family environment to be able to motivate and convince mothers in lactation management.
\end{abstract}

Keywords : Family support, Lactation Management, Mothers with toddlers 


\section{STRADA Jurnal Ilmiah Kesehatan}

DOI: $10.30994 /$ sjik.v9i2.364

ISSN: 2252-3847 (print); 2614-350X (online)

Vol.9 No.2 November 2020 Page.694-699

\section{BACKGROUND}

United Nations International Children's Emergency Fund (UNICEF) in 2008 estimated that exclusive breastfeeding for up to 6 months could prevent the death of 1.3 million children under the age of 5 years. research in Ghana shows that $16 \%$ of infant deaths can be prevented by breastfeeding since the first birth. This figure is up $22 \%$ if breastfeeding starts within the first hour after the birth of a baby (Ramlan \& Margawati, 2016). WHO World Data recommends the best pattern of feeding for infants from birth to age 6 months, then afterward supplemented with MP-ASI (complementary feeding) right after the baby is 6 (six) months, then breastfeeding continues until the child is 2 (two) years $(\mathrm{MOH}, 2017)$. The practice of exclusive breastfeeding in urban and suburban areas is still low, around 20-30\%. The Indonesian Government's target through the Indonesian Ministry of Health is targeting exclusive breastfeeding coverage of $80 \%$, but this figure is still very difficult to achieve (Syafiq, 2012). The results of the National Socio-Economic Survey in 2010, the scope of exclusive breastfeeding in Indonesia was still below the target, namely in infants aged 0-6 months with coverage rates of $61.5 \%$. Whereas in infants aged 6 months is still very low at 33.6\% (Ministry of Health, 2012).

The success of exclusive breastfeeding for 6 months in infants is largely determined by the manner and success of breastfeeding since. If it starts with the wrong method and strategy, the success of breastfeeding in the future is more difficult to achieve. Breastfeeding initiation must be planned and carried out from the beginning well so that the expectations of babies and mothers for exclusive breastfeeding can be optimized. Mothers who fail exclusive breastfeeding practice are due to a lack of knowledge and motivation. The low percentage of exclusive breastfeeding by the mother to her baby is a problem that needs to be sought for the cause, besides it needs to be evaluated why ongoing counseling has not given the expected results (Ambarwati et al., 2014). Breastfeeding started exclusively for the benefit of family and country because it can increase the bond between mother and baby, reduce morbidity, give more practical and economical. After all, household expenses to buy formula milk and the cost of caring for sick children will be reduced so that the country will have quality human resources (Lowdermilk, 2004). The main problems of the low exclusive breastfeeding in Indonesia are the influence of socio-cultural factors, lack of knowledge of pregnant women, families, and the community (Riskesdas, 2010), as well as health workers who have not fully supported the increase in breastfeeding (PP-ASI), including institutions that employ women who have not provided a place and opportunity for breastfeeding mothers at work (Kemenko, 2010)

The low exclusive breastfeeding can be caused by low levels of education and knowledge, work and trust, breast milk does not come out, nipples abrasions, and swelling. Besides, family quality factors that do not support exclusive breastfeeding, health workers do not promote the implementation of lactation management because they are influenced by the promotion of formula milk, or it can also be from negative socio-cultural influences. The results showed there was a relationship between family support and exclusive breastfeeding in infants aged 0-6 months (Hamidah, 2018). So, it is necessary to increase awareness and provide support to maternity to provide exclusive breastfeeding through involving the family. For working mothers, the cause of the lack of exclusive breastfeeding coverage is the short period of maternity leave, namely an average of only three months, limited time or busywork, and the availability of facilities for breastfeeding at work causes the use of bottled or formula milk given earlier. More and more women who work will affect the efforts of breastfeeding mothers. The nursing profession is a profession with a 


\section{STRADA Jurnal Ilmiah Kesehatan}

DOI: $10.30994 /$ sjik.v9i2.364

ISSN: 2252-3847 (print); 2614-350X (online)

Vol.9 No.2 November 2020 Page.694-699

relatively large percentage of female workers. Nurses are required to be a role model for the community, especially in the application of lactation management. Lactation management is an effort made by a mother to continue to provide breast milk for her baby during the postnatal period or breastfeeding, the scope of which includes exclusive breastfeeding, breastfeeding techniques, expressing milk, storing milk, giving milk, and fulfilling nutrition during breastfeeding (Agoestingoe, 2011). At present, there are still many working mothers including nurses who have not been able to carry out this role effectively.

The success of a mother to continue breastfeeding her baby is also influenced by support from the family. There is an effect of providing lactation management education on family support to mothers in giving ASI. Suggestions for health workers are expected to further enhance the educational activities of lactation management in the families of pregnant women (Rofiqoh et al., 2020). Families can provide support in the form of informational support, assessment/guidance support, instrumental support, and emotional support (Friedman, 2003). The most influential family support to the success of mothers in breastfeeding is emotional support and informational support (Simbolon, 2013). Providing support from husband and family can increase self-confidence, comfort, and experience of successful mothers in breastfeeding. Main never has seen mothers breastfeeding their babies, in the lactation room there is a seat for mothers and a place to wash their hands. Whereas the lactation room at Perinatology is often seen to be used by mothers whose babies are cared for, and only a small proportion of nursing nurses make use of this facility. Almost all rooms in Arifin Achmad Hospital in Pekanbaru have refrigerators/refrigerators that can be used by nurses to store milk, but not all nurses who are breastfeeding make optimal use of this facility. Most of these refrigerators are more widely used for storing medicine and food.

\section{METHODS}

Design This research is correlational studies. The study population is All mothers with babies. The sample used as many as 30 respondents with incidental sampling techniques. Independent Variable is family support. The dependent variable is lactation management. The research instrument using the Analog Number Scale (ANS) was adapted to the Likert scale. Stages of researchers obtained permission from STIKES Hospital. Baptist Kediri. Researchers got Ethical Permit from STIKES Hospital. Baptist Kediri. Researchers create applications using Google form in which there are educational videos of lactation management and choking baby management. The Google Form contained a questionnaire to measure family support and lactation management and data was taken during the Pandemic COVID-19 period. Statistical Test using Spearman's-rho.

\section{RESULTS}

Tabel.1 Lactation Management

\begin{tabular}{lcccccccc}
\hline \multirow{3}{*}{ Levels } & \multicolumn{7}{c}{ Family Support } \\
\cline { 2 - 9 } & \multicolumn{2}{c}{ Assessment } & \multicolumn{1}{c}{ Instrumental } & \multicolumn{2}{c}{ Information } & of Emotional \\
\cline { 2 - 9 } & & $\Sigma \%$ & & $\Sigma \%$ & & $\Sigma \%$ & & $\Sigma \%$ \\
\hline Pretty Good & - & - & 6 & 20 & 3 & 10 & 6 & 20 \\
\hline Good & 18 & 60 & 18 & 60 & 15 & 50 & 15 & 50 \\
\hline Very Good & 12 & 40 & 6 & 20 & 12 & 40 & 9 & 30 \\
\hline Total & 30 & 100 & 30 & 100 & 30 & 100 & 30 & 100 \\
\hline
\end{tabular}




\section{STRADA Jurnal Ilmiah Kesehatan}

DOI: $10.30994 /$ sjik.v9i2.364

ISSN: 2252-3847 (print); 2614-350X (online)

Vol.9 No.2 November 2020 Page.694-699

The results showed that most mothers had 23 years of age, namely $30 \%$ of respondents. The age of most babies aged 11-15 months is 30\% of respondents. The results showed that the most supportive family assessment support is good as many as 18 respondents $(60 \%)$, Instrumental Support is most good as many as 18 respondents $(60 \%)$, the most information support is good as many as 15 respondents (50\%) The most emotional support many are good as many as 15 respondents $(50 \%)$.

Table 2. Cross Tabulation and statistical test between Family Support and Management Lactation

\begin{tabular}{lcccccc}
\hline \multirow{2}{*}{ Lactation Management } & \multicolumn{3}{c}{ Family Support } & \multicolumn{2}{c}{ Total } \\
\cline { 2 - 6 } & \multicolumn{2}{c}{ Pretty Good } & \multicolumn{2}{c}{ Good } & & \\
\cline { 2 - 6 } & & $\Sigma \%$ & & $\Sigma \%$ & & $\Sigma \%$ \\
\hline Pretty Good & 5 & 16.7 & 14 & 46.7 & 19 & 63.3 \\
\hline Good & 1 & 3.3 & 8 & 267 & 9 & 30 \\
\hline Very Good & 0 & 0 & 2 & 6.7 & 2 & 6.7 \\
\hline Total & 6 & 20 & 24 & 80 & 30 & 100 \\
\hline
\end{tabular}

Description: Spearman Rho $p=0.025$, Correlation Coefficient 0.612

The results of the study found that the lactation management by the mother of the baby is good enough for 19 respondents ( 63.3\%), while the most supportive family support for infant mothers was 24 respondents $(80 \%)$. Most of the research results have good family support with quite a good lactation management of 14 respondents $(46.7 \%)$. The results of the study using the Rho spearmen test obtained $\mathrm{p}=0.025$ with a Correlation Coefficient of 0.612 which means there is a strong relationship between family support and lactation management.

\section{DISCUSSION}

The results of the study indicate that pregnant women have good family support. Family support plays an important role in the smooth process of breastfeeding and breastfeeding. Family support has a successful relationship in providing exclusive breastfeeding to mothers and families. Family support is support to motivate mothers in giving ASI and also support in giving psychologically to the baby's mother and prepare the best nutrition for nursing mothers. Family support is also very important to apply (Firmansyah et al., 2017). Family support is also given emotionally well from the family to pregnant women. One family that actively plays a role is the husband in giving ASI by providing emotional support and other instrumental assistance.

Mothers in giving ASI are not necessarily influenced by their behavior where the behavior of someone who will give exclusive ASI to someone will be different. A person's behavior toward health. Every situation in the family can be different, and there are also families in giving MP-ASI prematurely, and that is behavior This is likely due to other factors that influence the mother and family to decide in giving MP-ASI. (H. Suwardianto, 2013) Lack of knowledge about lactation management can be a contributing factor in maintaining breastfeeding for infants. There may also be an assumption that breastfeeding is not a modern thing by giving ASI. The thought can reduce the beauty and dislike of the husband as well as inadequate information on social media related to breastfeeding. So that mothers and families prefer to give through bottles with formula milk. Family support will show several different functions, namely information support, assessment support where 


\section{STRADA Jurnal Ilmiah Kesehatan}

DOI: $10.30994 /$ sjik.v9i2.364

ISSN: 2252-3847 (print); 2614-350X (online)

Vol.9 No.2 November 2020 Page.694-699

the family will guide the mother and mediate if a problem occurs. Instrumental support is where the family as a source of practical and concrete help and emotional support. Family support is very necessary because it relates to the mental and psychological family.

The results of the analysis found that the management of lactation by mothers is still not so optimal. Mothers have many formations or do not work like housewives, some work, and others. But some mothers understand about lactation management with good education so that they have good management. This can be applied in daily life in lactation management with her child. Lack of knowledge can affect lactation management in mothers. Knowledge in evaluating lactation management is also needed to support the mother in giving breast milk following the expectations of the mother and family. Good knowledge is not just a science but is also carried out as an act of mother to baby.

Good lactation management will show good lactation behavior. Good lactation management will support the fulfillment of good nutrition during the breastfeeding period for babies with appropriate breastfeeding processes and techniques. Good lactation management needs to be improved through education for mothers to be better. Good knowledge is not necessarily also have an impact on mothers giving exclusive breastfeeding to infants. Good knowledge will support a good attitude as well as can overcome any problems in lactation management eg choking problems (Suwardianto, 2018; H. Suwardianto, 2018). Because of the possibility of lactation management when the baby is experiencing an emergency that needs to be understood by the mother and also the family (H. Suwardianto, 2011; H. Suwardianto \& Richard, 2017; H. Suwardianto \& Selvia, 2015). But especially the mother's attitude in lactation management has an impact on exclusive breastfeeding. Because the attitude is more to the action or synthesis of knowledge that shows the real condition. Other factors that are likely to influence lactation management are working mothers, hours of breastfeeding, different ways of breastfeeding. The results showed that there was family support with lactation management. It showed that the process in lactation management had been implemented because there was good family support in line with the management of lactation. The role of the family is very high in changing mothers' attitudes in favor of changing attitudes for the better.

\section{CONCLUSION}

After conducting the study, it was found that the results of the study showed that the most supportive family assessment support was as many as 18 respondents $(60 \%)$, Instrumental Support was mostly as good as 18 respondents (60\%), the most information support was good as many as 15 respondents ( $50 \%$ ) The most emotional support is good as many as 15 respondents $(50 \%)$. The results showed a relationship of family support with lactation management in mothers and toddlers in the Pesantren District of Kediri City.

\section{ACKNOWLEDGMENTS}

We thank the Indonesian Ministry of Science, Research, Technology, and Higher Education (RISTEKDIKTI RI) for the 2019 Research Grant and the 2020 implementation. We are grateful to all parties and all the research respondents.

\section{REFERENCES}

Agoestingoe. (2011). Tingkat pengetahuan ibu bekerja tentang manajemen laktasi ibu bekerja berdasarkan karakteristik individu di kelurahan tugurejo Kecamatan tugu kota semarang. In Universitas Muhammadiyah Semarang.

Ambarwati, R., Muis, S. F., \& Susanti, P. (2014). Pengaruh konseling laktasi intensif 


\section{STRADA Jurnal Ilmiah Kesehatan}

DOI: $10.30994 /$ sjik.v9i2.364

ISSN: 2252-3847 (print); 2614-350X (online)

Vol.9 No.2 November 2020 Page.694-699

terhadap pemberian air susu ibu (ASI) eksklusif sampai 3 bulan. Jurnal Gizi Indonesia (The Indonesian Journal of Nutrition); Vol 2, No 1 (2013). https://doi.org/10.14710/jgi.2.1.

Depkes. (2017). Pedoman penyelenggaraan pelatihan konseling menyusui dan pelatihan fasilitator konseling menyusui. Jakarta.

Firmansyah, R. S., Lukman, M., \& Mambangsari, C. W. (2017). Faktor-Faktor yang Berhubungan dengan Dukungan Keluarga dalam Pencegahan Primer Hipertensi. Jurnal Keperawatan Padjadjaran, 5(2), 197-213.

Hamidah, S. (2018). Hubungan Antara Dukungan Keluarga dengan Pemberian ASI Ekslusif pada Bayi Usia 0-6 Bulan. Jurnal Midpro, 1(1), 1.

Kemenkes. (2012). Kinerja kegiatan pembinaan gizi tahun 2011 menuju perbaikan gizi perseorangan dan masyarakat yang bermutu.

Kemenko. (2010). Pemberian ASI Eksklusif di Indonesia Masih Rendah.

Lowdermilk. (2004). Maternity and women's health care. In Mosby.

Ramlan, R., \& Margawati, A. (2016). Pengaruh konseling gizi dan laktasi intensif dan dukungan suami terhadap pemberian air susu ibu (asi) eksklusif sampai umur 1 bulan. Jurnal Gizi Indonesia (The Indonesian Journal of Nutrition); Vol 3, No 2 (2015). https://doi.org/10.14710/jgi.3.2.101-107

Rofiqoh, S., Rejeki, H., \& Pratiwi, Y. S. (2020). Pengaruh Edukasi Laktasi Terhadap Dukungan Keluarga dalam Pemberian ASI di Kabupaten Pekalongan. Jurnal Ilmu Keperawatan Dan Kebidanan, 11(1), 153-157.

Simbolon. (2013). Pengaruh dukungan keluarga terhadap pemberian ASI Eksklusif di wilayahkerja puskesmas Gurilla Pematangsiantar. Universitas Sumatera Utara.

Suwardianto, heru. (2018). Pelatihan Penangganan Korban Tersedak Terhadap Pemahaman Tujuan, Prosedur, Kewaspadaan, Dan Evaluasi Tindakan. Jurnal Penelitian Keperawatan, 4(2), 1.

Suwardianto, H. (2011). Pengaruh terapi relaksasi nafas dalam (deep breathing) terhadap perubahan tekanan darah pada penderita hipertensi di puskesmas kota wilayah selatan kota kediri. Jurnal Kesehatan STIKES RS. Baptis Kediri, 4(1).

Suwardianto, H. (2013). Deep breathing relaxation as therapy to decrease blood preassure on hypertension patients. In Proceedings Faculty Of Nursing Of Airlangga The Fourd Internasional Nursing Conference Improving Quality Of Nursing Care Though Nursing Research and Innovations, 1(1), 1-12.

Suwardianto, H. (2018). Pengetahuan, Sikap Dan Perilaku Pencegahan Dekubitus Pada Keluarga Dengan Imobilisasi. Prosiding Seminar Nasional Dan Workshop Publikasi Ilmiah.

Suwardianto, H., \& Richard, S. D. (2017). Asuhan Keperawatan Kegawatdaruratan dan Penatalaksanaan Tindakan Kegawatdaruratan. CV Adjie Media Nusantara.

Suwardianto, H., \& Selvia, D. (2015). Buku Ajar Keperawatan Kegawatdaruratan (Perspektif, Konsep, Prinsip, dan Penatalaksanaan Kegawatdaruratan). PT. REVKA PETRA MEDIA.

Syafiq. (2012). Kajian implementasi dan kebijakan air susu ibu eksklusif dan inisiasi menyusu dini di Indonesia. Makara Kesehatan, 1(14), 17-24. 